\title{
War-affected Children in Three African Short Stories: Finding Sanctuary within the Space of Placelessness
}

\section{Annie Gagiano}

\section{(2) OpenEdition Journals}

Electronic version

URL: https://journals.openedition.org/ces/2198

DOI: $10.4000 /$ ces.2198

ISSN: 2534-6695

Publisher

SEPC (Société d'études des pays du Commonwealth)

Electronic reference

Annie Gagiano, "War-affected Children in Three African Short Stories: Finding Sanctuary within the Space of Placelessness", Commonwealth Essays and Studies [Online], 42.2 | 2020, Online since 30 September 2020, connection on 17 January 2022. URL: http://journals.openedition.org/ces/2198 ; DOI: https://doi.org/10.4000/ces.2198

This text was automatically generated on 17 January 2022



Commonwealth Essays and Studies is licensed under a Licence Creative Commons Attribution - Pas d'Utilisation Commerciale - Pas de Modification 4.0 International. 


\title{
War-affected Children in Three African Short Stories: Finding Sanctuary within the Space of Placelessness
}

\author{
Annie Gagiano
}

1 In this article, "place" is conceived as geographically locatable and concretely perceptible, but as simultaneously an emotional "space" or locus of feeling - with more emphasis placed on the latter perspective. If the presumption that narrative can take us to places as much as to placelessness is accepted, it does so in the short stories discussed here through the eyes and ears of their various child protagonists' apprehensions of bad places and fraught times, in emotionally coloured observations and responses more akin to paintings or drawings than to photographs or television footage. Being more than merely accurate recordings, evocations of both the places and non-places of the children's experiences go deeper and are more valuable than reporters' descriptions. The children become reliable witnesses ${ }^{1}$ with "the authority to describe atrocities," in the words of John Marx $(2008,599)$.

2 Edward Relph - widely recognized as the inventor of the "placelessness" concept arguably conceives placelessness from first-world perspectives of capitalist modernity, focusing on perceptions of structures and sites so uniform that locations appear indistinguishable, endlessly replicable, and anonymous. The form of placelessness experienced by war-affected African children in the chosen stories is of a different (and non-uniform) kind. Commenting years later on resurgent interest in his original text (1976), Relph himself stated that "the phenomena of place and placelessness are variable in both time and space" $(2000,619)$. A "place" is constituted by and has both geographical and historical features. Embroidering on his concept of the "chronotope" as "materializing time in space" or manifesting authors' ability "to see time in space" (1981, 250, 247; original emphasis), Bakhtin stated that it is "most important" to recognize "the weaving of historical and socio-public events together with the personal 
and even deeply private side of life" $(1981,247)$. This is how Tonderai's anguish for his father's sufferings and his love for Rudo in Marechera's story, the boy narrator's observing Monica's trauma and grief for her brother in Okri's, and Beniam's forgiving comprehension of his father's enduring fear in Mengiste's, respectively and uniquely influence the complex evocations of time-space narrated in the three texts.

The three stories are brought together here inter alia for comparative purposes and the present article presents a modest "reply" to Rita Felski and Susan Stanford's question, "how do we rethink the spaces of comparison in order to do justice to past and current postcolonial and global contexts?" (2009, v). Preoccupation with the news of the day and with one's immediate surroundings would put the Zimbabwean Liberation War, the Biafran War, and also the war conducted by the Ethiopian Derg regime upon their civilian population beyond the ken or interest of most outsiders. Two Shona children in a concentration camp, a twelve-year-old Igbo girl refugee in Nigeria, or an Ethiopian boy in Addis Ababa who later on lives as a refugee child in Los Angeles, would "disappear" amidst the unmournable ${ }^{2}$ masses of collateral damage in faraway, longago, "irrelevant" African conflicts, were it not for what Edward Said terms the "human work" $(1991,21)$ of Marechera, Okri and Mengiste in these stories - if allowed a place in the house of fiction. Shu-mei Shih observes suitably that any "place" needs to be seen as "a nodal point of connection [which] produces and embodies relations on the world scale, however small or marginal it might be," since what happens there occurs "in the context of world history" $(2016,723)$.

4 The intensity and concentration of the short story form lends itself well to evocations of the fright of war, while adoption of child narrators and focalizers endows the chosen stories with especial poignancy because of children's undeniable physical and emotional vulnerability - deeply challenged under the circumstances described. The affective freighting of the chosen stories leads readers through emotionally evaluative response to understanding. ${ }^{3}$ Choice of a child witness to war's devastation is thus a "technique" expressive of an author's appeal to human connectedness. ${ }^{4}$ Short stories focused on a relatively small place may nevertheless deftly enlighten a "large" history by showing an individual life's entanglement with political, social and familial circumstances.

5 Dambudzo Marechera's moving, powerful short story "The Camp" was written in 1986 and published posthumously in 1994 in the Scrapiron Blues collection. ${ }^{5}$ The first part of the story, which is entitled "The Concentration Camp," signals an infamous war-time place used by oppressors or a country's invaders to contain and intimidate inmates in what is actually illegal incarceration and (usually violent) displacement. Flora VeitWild, the editor of the collection featuring this brief story, reports as follows:

In "The Concentration Camp", [...] Marechera again employs the children's perspective, this time to express his horror of the Zimbabwean war of liberation. He describes life in the "protected villages", the "keeps", in which parts of the rural population were kept by the Rhodesian army [...]. He shows how their inmates were subjected to traumatizing acts of brutality: beatings, torture, helicopter attacks [...] [;] he talked about his methods and ideas while writing "The Concentration Camp": [....] "So I am not just exploring the concentration camps, I am trying to bring out the psyche, the psychological personality of that particular period, especially from 1978 to the end of 1979, to Independence. Because the most dangerous time for those in the concentration camps was when the Ian Smith soldiers knew that they were losing the war." (1994, XIII-XIV) 
6 The story unforgettably evokes a brief period in the lives of two Shona children, Tonderai (a nine-year-old boy, whose name is significantly the imperative form of the verb "to remember" in Shona) and Rudo (a slightly younger girl, whose name means "love"). They have been forcibly incarcerated along with their own and a few other surviving peasant families in a concentration camp after their village (like many others at this time) was razed and hundreds of its inhabitants killed by Rhodesian forces, on the justification that indigenes help sustain guerillas of the liberation forces. The camp is cruelly guarded by black, local soldiers intent on proving their zeal in serving the white Rhodesian settler camp administrator. ${ }^{6}$ The camps - in which peasant families live in fear - were cynically called "protected villages." The white administrator justifies the atrocities of settler oppression at this time by sneeringly referring to the indigenous population as an ever-expanding infestation ("breed[ing] like flies," 159). His black deputy endorses this with nauseating enthusiasm, but Marechera undermines this complacency by depicting white settler rule as parasitical usurpation of others' toil and land, maintained by terrorism. Soldiers torture and kill adult males on flimsy pretexts during interrogations and grope or rape women prisoners, while planes strafing cattle-herding boys demonstrate transgressions of the Geneva Convention. The illocutionary force of the text allows readers to grasp the facts of the account as individually experienced realities, distinct from broadly generalized accounts of the war as a period and site - Tonderai's father's decline and approaching death following grievous torture is perceived through the boy's anguished eyes, while Rudo is exposed to grinning camp guards humiliating her mother by sexual taunts and groping, and Tonderai (bleeding from a head wound) recovers consciousness in the veld to see several of his friends' corpses after the unprovoked airborne attack on the camp's herd-boys.

7 Under what may be considered normal familial circumstances, parents as guardians of children's safety and well-being create "place" even in crisis times or when homeless. In the concentration camp, the parents' subjugation by the brutality of their guards causes the children harrowing anxiety about their parents' chances for survival, feelings so strong that they are pushed into the formless, terrifying "space" of placelessness. Tonderai could not but "know with certainty that his [tortured, starving] father was dying," thoughts that "drew his mind away from the world" (Marechera 1994, 160) into a horrifyingly featureless limbo. When four of his fellow herd-boys are shot dead from an aeroplane while looking after the villagers' few remaining cattle, the uncaring, brutal gaze of the African sergeant staring down at him and callously ordering the wounded child to walk back to the camp becomes (in Tonderai's mind) a displacing force more devastating than a physical attack. The man's stare focuses "all the darkening twilight of the universe" (161), obliterating physical landmarks and emotional orientation points in an engulfing placelessness. Although the only "medicine" his father has to treat Tonderai's head wound is a bit of Vaseline, his gentle touch returns the boy to familial connectedness.

8 Tonderai has been grievously injured in the raid. Rudo, the little girl who cares deeply for him and whom he loves (without the children using these terms), "took his hand in hers, and held it in her lap" and this tender, "placing" gesture "exorcised out of his otherworld the brisk inevitability of paralysis" (Marechera 1994, 163). Rudo's cherishing look and Tonderai's reciprocation of her gentleness make clear that (however much of an illusion this may be in their actual space of extreme vulnerability) 
the children provide for each other a "place" of safety: a sanctuary. Although "death was everywhere" and despite perhaps sensing that "in conditions of brutish survival, affection was [...] a weapon for the enemy," their "joined hands" are an enduring emblem of love's "terribly sweet" power to create temporarily inviolable spaces where these endangered children feel grounded and located by the gentle strength of their bond (163).

9 Marechera's brief (five-and-a-half-page) narrative's emotional intensity is deeply poignant in its evocation of two young children caught in the jaws of war. He wrote "The Concentration Camp - Part One" in 1986, soon after his return to postcolonial Zimbabwe from Britain, yet his story gives vivid life to wartime conditions experienced locally. Marechera had noted at the time that "Nobody talks about the war" $(1994,43)$. His story insists on remembrance and honours this war's innocent victims. "The Camp (Part One)" is a postcolonial short story of "haunting resonance" that penetrates to "the most rotten core of war - its abuse of children" (Gagiano 2005, 50-51), evoking the irreplaceable value of the depicted lives of children and bearing witness to war's desecration of this core principle of human existence. Cruelty coexists with loving care and protective courage in the complex space of war, unforgettably delineated in this brief narrative.

10 Shu-Mei Shih's concept of "relational comparison" $(2018,430)$ can serve to describe the reading practice employed in bringing the three chosen stories together in this article. The stories depict three widely separate African countries, spatially speaking, and different - if somewhat overlapping - times of war $^{7}$ in these settings, nevertheless sharing certain aspects through which they can be linked. All three depict children inhabiting the space of suffering. The delicacy and verbal skill by means of which the three authors give readers access to the emotional spaces within the child characters demonstrate comparable artistry in overcoming what Judith Butler has called "the problematic of the articulation between what cannot be said and what should be said" $(2013,133)$ by honouring rather than desecrating the mourning and pain of the child characters.

11 Alicia C. Decker (in "Pedagogies of Pain") refers to "children's gendered experience of war" $(2010,84)$. The cited expression is evidently appropriate to Okri's story, but also (in more understated ways) to Marechera's and Mengiste's. Ben Okri's "Laughter beneath the Bridge" (from his 1986 collection Incidents at the Shrine) depicts a narrating character, an unnamed, ten-year-old boy, who filters Okri's account of a slightly older, pubescent girl named Monica - actually the main focal character of the story. She is triply displaced as the remaining member of a war refugee family, as member of the "hunted" ethnicity (presumably the so-called "rebel tribe" (1) of Eastern Nigerian Igbos that sought secession from Nigeria ${ }^{8}$ ), and as a girl whose family members have been "pursued from their house" (a single room) by "the townspeople," and "scattered in the forests" (11). Monica's beloved brother Ugo has been killed by the aggressors. Her family used to live next-door to the narrator. She has been given charitable shelter by the boy's parents, but in her traumatised state worries them by her risk-taking conduct. The boy's mother calls Monica "stubborn": she has already had to be rescued from a "soldier" (a member of the Nigerian occupying army) by the boy's father. The (younger) boy is fascinated by Monica, playing peeping Tom on her budding sexuality. His mother enjoins him to "speak to" Monica, saying: "the way she is behaving they will kill her before the war is over" (11). The boy and perhaps also the parents do not 
understand the terrible placelessness of emotional desperation and isolation in which Monica finds herself.

Okri's is the longest of the three stories and has attracted more literary recognition than the other two evocations of war-affected children. Eleni Coundouriotis's and Sarah Abdullah's articles (of 2015 and 2017, respectively) are worth noting. Evoking two specific events in the Okri story, Coundouriotis's phrasing allows me to extend the notions of placelessness that I have introduced here. She comments on two depicted occasions when first the boy and later Monica burst into strange, misplaced laughter under horrifying circumstances:

In both instances [...] the subjects confronted with violence beyond the pale succumb to a fit they can't control, their body assuming a volition of its own. In each circumstance, the stench of the dead bodies and the uncontrollable laughter of the witnesses derail the realist account of the war to some other domain. (1094)

13 I suggest that this "other domain" is the uncanny sphere of the unbearably shocking, since neither child can accept that actions as appalling and disgusting as those confronting them during the war can be thought of as real or believable; they fall (as the child witnesses seem to continue to believe) outside the human realm known to them and are thus "out of place."

Abdullah compares Monica to Antigone: the surviving sister who dares to ritually mourn her dead brother $(2017,3)$, even when this is defined as treason to the state or those in power. The boy (unlike Monica) is privileged - he has been fetched by his mother from his Catholic boarding school. Two other abandoned boarders can merely continue to wait for someone to return them to a safe space of belonging. On the harrowing journey home the boy avoids thinking about the sight of multiple corpses abandoned by the roadside, the plight of women gang-raped by soldiers at road blocks and of hopelessly trudging streams of refugees (all made placeless by war) by dreaming of Monica, hence accessing a site of refuge. While the boy appears to witness one horribly extended gang-rape dispassionately, he has a premonition when their journey continues without the violated woman. He is thinking of "Monica, who did only what she wanted," "wonder[ing] if she would have long enough to say a word when they came for her" (Okri 1986, 9), sensing her precariousness. A soldier's leering response to Monica back in the village where the military have mounted another roadblock across from the bridge is another warning that even Monica shrinks from, but she leads the boy down the river-bank on the other side of the bridge to the place (it turns out) where she goes to mourn her brother, since that is where she found his dead body (which has since floated away). To Monica a shrine, this place is a site of horror; the river clogged with other foul-smelling, bloated corpses. The "laughter" the children burst into in what Okri identifies by his title as his story's key site is not that of children happily at play or the naughty giggling of youngsters canoodling, an activity in which the boy had hoped to engage with Monica. It is instead (in Monica) a griefmaddened expression of her emotional desperation in view of the desecration inflicted on her cherished brother. This place has become an unholy space: the placelessness of Monica and her people performed in the most horrific expressions of contempt both by the local villagers and by the occupying federal soldiers. Okri's ability to give verbal shape to Monica's "felt" experiences recalls Bakhtin's statement that in the chronotope "the epoch becomes not only graphically visible [space], but narratively visible [time]" (1981, 247; original insertions). Placelessness cannot be given physical visibility, but may be narrated. 
15 Monica hereafter performs her grief and fury at the depravity and shame of the space in which she is entrapped by assuming (against the strict gender rules of the local culture) the role of the masked Egungun - ritual embodiment of a leading (male) ancestral spirit and the time-honoured values that were discarded in the violent dispersal of her family and the murder of her brother (deeds violating the sacred rule of the provision of shelter to those in need). But "defying" the occupying military by leading the masquerade expressly forbidden by them brings Monica's undoing and further acts of desecration. The mask is torn off her (disrespecting a masquerade being considered a most dreadful "religious crime" in entering the sacred space of the Egungun) and, by seizing the hysterically frightened girl-child and abducting her (Okri $1986,21)$ to a place well outside the town borders where she will undoubtedly be gangraped and murdered, the men enact a desecration of humanity. The horror of the event is intensified through the boy narrator's slowly achieved understanding of Monica's nature, her courage and moral integrity. The boy recognises the irreplaceable loss to the community. Yet he will not forget Monica's ability to make "something [shift] in [his] eyes" (17). As a moral marker, she has a place of honour in his memory.

16 The above idea of certain instances of human conduct serving as "limit cases" indicative of the borders of humanity, with an author evoking this acting in the role of moral cartographer recording the boundaries of ethical space, may be linked with a remark by Maaza Mengiste. In a presentation entitled "Creative writing as translation," she stated: "Our task as writers is to explore the fine lines between what is seen and how it is described; what is known and how it is re-rendered" (2012b, 940). One may add, what is it that distinguishes writing that renders traumatic events ethically from the reporting or the rendition of similar (or the same) events exploitatively? Mengiste's brief but rich statement speaks directly of an authorial duty to create literature evincing respect for readers, for the characters created, and regarding the lifechanging events or situations described in her implicitly evaluative description especially when the temptation exists to yield to the more striking features of such incidents in emphasizing the sensational and write from the perspective that has with horrid aptness been termed "trauma porn." Mengiste's remarks allow us to see that both in authorial approach and in textual effect - the impression created by what has been written - there needs to be an ethical dimension. The text (in this case, the postcolonial short story) recreates a particular place and allows access to an event in time. The three short narratives construct commemorative spaces: even so, an imperceptive or insensitive reading may have an inappropriate or merely short-lived effect, relegating the text or the "epoch" to placelessness. The reader may effect a "rerender[ing]" (Mengiste's term) that distorts - parodies, soils, or ruins - the author's intended effect, or the textual creation, misplacing it. Both writer and reader have the responsibility to respect the mourning and suffering of depicted characters that "stand in" for actual persons subject to dreadful conditions.

17 The third short story concerning a war-affected child selected for this article is "A Good Soldier" (2012) by Maaza Mengiste. ${ }^{9}$ Her first novel, Beneath the Lion's Gaze (2010), is set during the Ethiopian Revolution and continues up to the point where the infamous Derg regime initiates what was to become known as "The Red Terror" 10 - its nadir, and the tipping point at which effective resistance to the infamous regime began - whereas the earlier part of the shorter narrative appears to be set during the time when the "Red Terror" was in full swing, causing the boy Beniam (usually referred to as "Benny") 
and his father Mesfin Gebregiorgis to flee to the United States to live in Los Angeles. The Ethiopian period and place dominate the account in many flashbacks focalized through the boy and sometimes his father. Place-setting is highlighted from the start in this story, which opens in the small flat in Los Angeles that they share with Mesfin's former bandmate and friend Leul, who helped them to escape from Addis Ababa. Both Benny and his father are refugees who had had to hide out in "a falling-down building in Khartoum" (Sudan) for six months after "fleeing soldiers" in Ethiopia - especially at the many checkpoints set up by the Derg (Mengiste 2012a, 129). Mengiste's talent for vividly and deftly evoking place ${ }^{11}$ by means of few but carefully selected details is notable throughout the narrative. However, placelessness too is powerfully evoked throughout the story. The father, especially, is not shown as having formed any kind of social connection with Americans, and apart from Leul's co-habitation with them, avoids all gatherings where the many Ethiopians living in Los Angeles congregate. But Mesfin's placelessness goes much deeper: he has lost his moral bearings because of the extreme guilt eroding his being - having (under torture) betrayed his adored wife Emebet and so all but destroyed his family. Her incarceration, the torture it would have entailed and her "disappearance" (of course indicating her death), followed by the soldiers' threat to take Beniam, too, have virtually unhinged him. Mesfin (in a dreadful parody of paternal protectiveness) has decided that this little boy of ten must be prepared and trained in a hardening process so as to resist the torture to which he, too, the father believes, will be subjected - so as not to break under torture (like his father) and betray family and friends to the torturers.

Mesfin's terror at the danger he believes the Derg continues to represent to himself and Benny never lets up - but the horror intensifies when the very military officer who was his chief interrogator turns up at the Los Angeles restaurant where Mesfin is employed as a waiter, suavely threatening his terrified compatriot by telling him that he had better keep his mouth shut about this evil torturer's presence in the American city. The setting of the scene where the man threatens Mesfin in the restaurant actually intensifies its horror, for the torturer does not create a "scene" in conveying his message. The fact that he has tracked down his victim yet again, still wielding the power of terrorism over Mesfin - and hovering so near to Beniam, after the loss of Emebet, the most precious and vulnerable presence in his life - indicates Mesfin's horrifying emotional precarity. Entirely dislodged now from his earlier sense of precarious but comparatively secure refuge in America, Mesfin floats in his shock to a time-place that no longer exists: when he could (as a band leader and beloved singercomposer before his ruination) sing of his devotion to and yearning for Emebet, "with an untainted voice springing from a loyal heart" (Mengiste 2012a, 135). At events where the band performed, Emebet had sometimes sung, too; at "other times she was the first to stand and dance [the] eskesta" (133).

Before his father's arrest, their home in Ethiopia was a space of ease and openness, where Benny lived shielded by love of and for his parents: a child fully placed and belonging:

Life [...] was a series of handclaps and foot races, marble games and American movies. His mother laughed. Her eyes sparkled like water in the sun. Her long hair flowed down her back like a dark, soft ribbon. His father sang for a band called the Golden Sounds of Ethiopia. He had a voice that trembled like a leaf in the wind. They lived in a home near the centre of Addis Ababa with two bedrooms and one bathroom. [...] There was no shooting at night. No soldiers breaking down doors and 
coming back to leave fathers on verandahs. No father waking him up in a tiny Los Angeles apartment empty of his mother, asking about breakable boys. (Mengiste 2012a, 130)

After his father's arrest, Benny's mother tried to maintain the boy's sense of home as a space of security and of his father's innocence, righteousness and important art, while giving him an explanation for why a cruel regime would jail the gentle Mesfin by telling Benny that his band "turned love songs into battle cries" and that "he had the power to bring people to their feet" (Mengiste 2012a, 132): "They loved him and a revolution always starts in the name of love [...]. They took your father to silence him, but once a voice is heard, [...] it is free" (132). The effect is ineffably sad when the beautiful natural imagery with which their pre-war existence was described recurs in a twisted way as Mesfin in agony remembers the moment in jail when, fingernails torn out and hands broken, "his wife's name was pulled out of his body, quivering like a drop of water hanging on a dead leaf" (135). He had identified her and others as members of their anti-Derg revolutionary group. After that, they took him home and threw his broken body like rubbish on their doorstep, snatching Emebet "out of Benny's embrace" (129), where she belonged.

Throughout this narrative, the Addis Ababa jail (where the parents were kept) represents the realm of hell - the sphere of the damned - and the extreme form of placelessness. All who enter it are destroyed no matter whether they end up dead or released. They can, like Mesfin, never get out of it again since it indelibly taints the soul. While the narrative point of view in the story shifts between Beniam and his father, Mengiste clearly indicates that even if Mesfin never speaks of his time in jail, nor admits to his son that the loss of his mother was the result of his betrayal, the boy recognises the traces of these events in his father's manner - as distinctly as he once saw the scars of torture on his father's body. This renders the flat in California an unsafe space of perpetual endangerment in which Beniam is under the un-childlike pressure always to be "prepared" for the worst - and simultaneously bears the burden of the promise his mother exacted from him (while his father was incarcerated) to "do everything" he could "to help [Mesfin]," once released (Mengiste 2012a, 137).

The evening after the torturer's restaurant visit, Mesfin further increases the abusive yet poignantly understandable pressure he puts on Beniam by intensifying the child's "training" - taking Beniam to a sphere closely resembling the space of imprisonment and torture. He ties up the boy, wrists to ankles, in the knot shape excruciatingly distorting the human body - as Mesfin was tied when casually tossed back onto his doorstep by the Derg's soldiers. The knot symbolically resembles Mesfin's mind and feelings as a result of perpetual fear, paralleling the "knot" (Mengiste 2012a, 137) in the boy's stomach as his father leaves him (still tied up) on the floor of their living room. Leul has gone to work. When after what seems like hours, Benny starts screaming from the pain - calling out "'Daddy! Daddy!"' as if to the tenderly loving father Mesfin used to be - the latter comes and releases the boy, ominously promising further such sessions by whispering "It'll get easier" and "You'll get used to it. I promise" (140). Mesfin believes that he is fulfilling the now painful, but sacred duty of protective fatherhood, his mind unhinged by fear. Yet an obscure awareness that what he is demanding from a little boy is appallingly abusive shows in the fact that "his father's tears were falling as fast as [Benny's]" (140). Mengiste's story ends with an image of featureless darkness that may be occurring in Mesfin's memory of his jail-time, or apply to the Los Angeles flat: "Night grows and swallows the day" (141). It is in either 
case, a fitting image of Mesfin being engulfed by the placelessness constituted by his sorrow, fear and torturing guilt. Such an image serves to link the way placelessness is evoked here with how it is represented by Marechera (in Tonderai's anguish about his dying father) and with what Okri makes the reader sense in Monica's wild "laughter beneath the bridge." Beniam's enduring, cherishing love for both his parents provides the boy with an inviolable place of shelter. His evident, instinctive understanding that Mesfin acts out of (albeit twisted) love preserves Benny from blaming a man deranged by fear. Although this places a ten-year-old boy in an unnaturally "parental" position, Benny's tender compassion allows him to shoulder this burden with enduring grace.

Mengiste's harrowing short story, like Marechera's and Okri's, counters its awful details with an innate gentleness of authorial vision - an unmistakable colouring of the evocations discernible in the ethically evaluative approach that unflinchingly examines the cruelties of war and war-like conduct. This affective dimension of each text refuses to yield to horror and is most strongly present in the way the three authors respectfully evoke the child characters. ${ }^{12}$ This creates the poetry in the pity. ${ }^{13}$ The importance of postcolonial African authors' complex depictions of fraught histories and settings being given space in the "house of fiction" lies in the urgency of replacing simplistic "new Dark Continent narrative[s]" by those "reporters" who are "the lineal descendants of the explorers and missionaries of the nineteenth century" (Falola and Ter Haar 2010, 2), who fail to represent embedded histories, places and people in the subtle and qualified ways that this occurs in the best of African postcolonial writings as in the stories featured here. Édouard Glissant's insistence that the world-space is the setting of an "infinite interaction of cultures" $(1997,173)$ remains valid. Ostensibly faraway spaces are as close (or remain as far) as our reading perspectives and choices allow them to be. I add as a concluding citation Boaventura de Sousa Santos's point: "intercultural [...] translation" $(2018,80)$, he suggests, "is an act of intermediation that allows one to turn the strange into the familiar, the far into the near, the alien into the common" (79; paraphrasing an earlier text of his own). Concepts of place and placelessness, we conclude, are richly productive as applied to the postcolonial writings and sites of our time.

\section{BIBLIOGRAPHY}

ABDULLAH, Sarah. 2017. “'The Young Shall Grow': Violence, Conflict and Coming of Age in Ben Okri's 'Laughter beneath the Bridge." Journal of Literature, Languages and Linguistics 37: 1-6. BAKHTIN, Mikhail M. 1973. "Concluding Remarks" to "Forms of Time and Chronotope in the Novel." In The Dialogic Imagination: Four Essays, edited by Michael Holquist and translated by Caryl Emerson and Michael Holquist, 243-57. Austin: University of Texas Press, 1981.

BUTLER, Judith. 2010. Frames of War: When Is Life Grievable? London: Verso. BUTLER, Judith. 2013. “Dispossessed Languages.” In Dispossession: The Performative in the Political by Judith Butler and Athena Athanasiou. Cambridge, UK: Polity. 
COUNDOURIOTIS, Eleni. 2015. “Things of Poverty and War: Ben Okri and Thing Theory." Callaloo 38, no. 5: 1087-99.

DECKER, Alicia C. 2010. “Pedagogies of Pain: Teaching “Women, War, and Militarism in Africa.”' In Falola and Ter Haar, 79-97.

FALOLA, Toyin, and Hettie TER HAAR, eds. 2010. Narrating War and Peace in Africa. Rochester: University of Rochester Press.

FELSKI, Rita, and Susan Stanford FRIEDMAN. 2009. Introduction: “Comparison." New Literary History 40, no. 3: V-IX.

GAGIANO, Annie. 2005. "Marechera's Wordhorde and the Scrapiron of War." In Versions of

Zimbabwe: New Approaches to Literature and Culture, edited by Robert Muponde and Ranka Primorac, 41-54. Harare: Weaver Press.

GAGIANO, Annie. 2010. "Ice-Candy-Man and In the Country of Men: The politics of cruelty and the witnessing child." Stellenbosch Papers in Linguistics 39: 25-39. DOI: 10.5774/39-0-2

GLISSANT, Édouard. 1997. Poetics of Relation. 1990. Translated by Betsy Wing. Ann Arbor: University of Michigan Press. Originally published as Poétique de la Relation (Paris: Gallimard, 1990).

LARA, Maria Pia. 1998. Moral Textures: Feminist Narratives in the Public Sphere. Berkeley: University of California Press.

MARECHERA, Dambudzo. 1992. "Dambudzo Marechera Speaks of Poetry." In Cemetery of Mind: Poems by Dambudzo Marechera, compiled and edited by Flora Veit-Wild, 206-17. Harare: Baobab Books.

MARECHERA, Dambudzo. 1994a. “The Alley” [A Play]. In Scrapiron Blues, compiled and edited by Flora Veit-Wild, 32-47. Harare: Baobab Books.

MARECHERA, Dambudzo. 1994b. “The Camp." In Scrapiron Blues, compiled and edited by Flora VeitWild, 158-63. Harare: Baobab Books.

MARX, John. 2008. “Failed-State Fiction.” Contemporary Literature 49, no. 4: 597-633.

MENGISTE, Maaza. 2010. Beneath the Lion's Gaze. London: Jonathan Cape.

MENGISTE, Maaza. 2012a. “A Good Soldier.” In The Granta Book of the African Short Story, edited and with an introduction by Helon Habila, 129-41. London: Granta.

MENGISTE, Maaza. 2012b. “Creative Writing as Translation.” Callaloo 35, no. 4: 939-42.

OKRI, Ben. 1986. "Laughter Beneath the Bridge." In Incidents at the Shrine. London: Heinemann. 122.

owEN, Wilfred. 1968. "Preface." In The Collected Poems of Wilfred Owen, edited with an introduction and notes by C. Day Lewis. London: Chatto \& Windus.

RELPH, Edward. 1976. Place and Placelessness. London: Pion.

RELPH, Edward. 2000. “Author's Response: Place and Placelessness in a New Context.” Progress in Human Geography 24, no. 4: 617-19.

SAID, Edward. 1991. “The Politics of Knowledge.” Raritan 11, no. 1: 17-32.

SANTOS, Boaventura de Sousa. 2018. The End of the Cognitive Empire: The Coming of Age of Epistemologies of the South. Durham: Duke University Press.

SHIH, Shu-mei. 2015. “World Studies and Relational Comparison.” PMLA 130, no. 2: 430-38. 
SHIH, Shu-mei. 2016. “Theory in a Relational World.” Comparative Literature Studies 53, no. 4: 72246.

TUMA, Hama. 1993. The Case of the Socialist Witchdoctor and Other Stories. London: Heinemann.

VEIT-WILD, Flora. 1992. Dambudzo Marechera: A Source-Book on his Life and Work. London: Hans Zell.

WIEBEL, Jacob. 2017, November. “The Ethiopian Red Terror.” Oxford Research Encyclopedia of African

History. DOI: 10.1093/acrefore/9780190277734.013.188

\section{NOTES}

1. See Annie Gagiano's article on “The politics of cruelty and the witnessing child” $(2010,25)$.

2. Alluding here to Judith Butler's question, When Is Life Grievable? in her subtitle to Frames of War (2010).

3. Compare Maria Pia Lara's remark (citing two of her own key concepts) that "narratives that possess such 'illocutionary force' [i.e.: a combination of power to move readers emotionally; intellectual persuasiveness and vivid rendition] have the 'disclosive' [i.e. revelatory; enlightening] ability to envision normatively" (1998, 6 - author's single quotation marks; parentheses and emphasis added).

4. Dambudzo Marechera expressed awareness of "certain techniques, certain concentrated, even visionary apprehensions of reality [required by writers] in order to convince the reader that the suffering [depicted] is unique and meaningful and, at the same time, a universal expression of life" (Marechera 1992, 211).

5. In her introduction to the posthumously published collection Scrapiron Blues (1994), the editor Flora Veit-Wild states that "The title - which Marechera added later - is a line from 'The Concentration Camp,' written in 1986” (1994, XIII).

6. The "Second Chimurenga" or "the Rhodesian Bush War" occurred 1964-1979 (the dual title reflects political-racial divisions enduring beyond liberation into the present). Ian Smith's settler government unilaterally declared Rhodesia's independence from formally concluded British Colonial rule, hence the acronym UDI. War deaths are estimated at 45 to 100-thousand; famine probably killed millions and refugee numbers are estimated between a half and 3 million. Rhodesia gained independence as Zimbabwe in 1980.

7. The Zimbabwean Liberation War dates are 1964-1979; the Biafran War's 1967-1970, and the Ethiopian "Red Terror" period under the Derg lasted from 1976 to 1977, following the revolution that overthrew Haile Selassie.

8. Okri's own mother was half-Igbo; she had to be kept hidden during the war and though a little boy then, he, too, narrowly escaped death during the upheaval.

9. She left Ethiopia aged four, with her family, fleeing the violence; three of her uncles died as anti-Derg fighters.

10. An excellent, detailed account of this period by Jacob Wiebel, titled "The Ethiopian Red Terror," is available in The Oxford Research Encyclopedia of African History (2017, 1-26), which confirms Mengiste's rendition (in both the novel and the short story) of the extremity of this regime's brutality. Though "Red" refers primarily to the (at the time) Russian Communist affiliation of the Derg, the term is usually understood as indicating this period for its bloodiness in the number of lives lost and the extreme viciousness of its torture practices. A well-known earlier, mostly sardonic rendition of the regime may be found in Hama Tuma's 1993 collection of short stories, The Case of the Socialist Witch-Doctor and Other Stories.

11. Her story's title ("A Good Soldier") can be seen as an unobtrusive reference to the place that is the source of Mesfin's emotionally devastating placelessness - the Addis Ababa prison where 
he was tortured, and to which he fears his son may be taken some day - a dreaded ordeal for which he prepares Benny as a tough "soldier."

12. In another article, Gagiano points out how child figures serve "as affective index of the appalling" $(2010,34)$; nevertheless the child characters in the narratives discussed above are never mere authorial instruments.

13. Alluding to Wilfred Owen's "Preface" to his Collected Poems $(1968,31)$.

\section{ABSTRACTS}

In short stories by three postcolonial African authors depicting war-affected children Zimbabwean Dambudzo Marechera's “The Camp” (1994, written in 1986), Nigerian Ben Okri's "Laughter beneath the Bridge" (1986) and Ethiopian Maaza Mengiste's "A Good Soldier" (2012) the child protagonists are displaced and exist in precarious spaces of unbelonging. The conditions vividly evoked from these war-affected African children's perspectives indicate that the unaccommodating "places" where the children find themselves propel them into terrifyingly featureless, engulfing and unrecognizable "non-places," in need of sanctuary as a place of safety. Yet even in such places of desperation, the children somehow retain or find precarious shelter in "places" of love, tenderness and loyalty.

war-affected children, Zimbabwe, Nigeria, Ethiopia, displacement, sanctuary

\section{AUTHOR}

\section{ANNIE GAGIANO}

\section{Stellenbosch University}

Annie Gagiano is a Professor Emerita in the English Department of Stellenbosch University. She is the author of two books - Achebe, Head, Marechera: On Power and Change in Africa (Lynne Rienner, 2000) and Dealing with Evils: Essays on Writing from Africa (ibidem-Verlag 2009; $2^{\text {nd }}$ ed. co-publ. Columbia University Press, 2014) - and of more than 70 articles and book chapters concerned with African fiction in English (or English-translated) from across this continent. 